\title{
Translating Inspired Language, Transforming Sacred Texts: An Introduction
}

\author{
Fatma Sinem Eryılmaz \\ Department of Modern and Contemporary History, Faculty of Philosophy \\ and Humanities, Universitat Autònoma de Barcelona \\ FatmaSinem.Eryilmaz@uab.cat
}

\begin{abstract}
In late medieval-early modern Iberia, translations of sacred texts often involved changes beyond those concerning linguistic and cultural frameworks. The sacred nature of the source text turned it into a potentially powerful tool for a variety of purposes. Translations were used to advance didactic and cultural policies and to disseminate political and religious propaganda. They became building blocks for communal identities under fatal threat. When need be, they could be manipulated both as weapons of self-defense or of belligerent attack against rival religiosities and institutions that harbored them. The power generated by the divine authority that spoke through sacred texts also made their translations and their translators, targets of suspicion and victims of strict control, and at times, destruction. The five articles that I introduce represent a wide spectrum of these possibilities as they examine translation projects of Christian, Jewish, and Muslim sacred texts and the transformations they catalyzed.
\end{abstract}

\section{Keywords}

translating sacred texts - Bible - Torah - Qur'ān

The decision to prepare a volume of articles on the topic of translating sacred texts grew out of the rich discussions that took place several years ago at a workshop organized by the European research group "Conversion, Overlapping Religiosities, Polemics and Interaction" (CORPI). ${ }^{1}$ There, shorter versions of

1 The workshop on "Translating Sacred Texts" took place on 13 January 2015 at Consejo de Investigaciones Cientificas (CSIC) in Madrid. CORPI was a project funded by the European 
some of the articles in this collection were presented. In time, with the addition of other articles, this volume has been prepared within the framework of the research project "Orientalism and Truth. The Influence of Eastern Erudition in the Development of Critical Thinking in Early Modern Spain." ${ }^{2}$

The articles that follow all examine translations of sacred texts linguistically. At the same time, they reveal to us, albeit in varying degrees, the particular histories of these translations. These are histories of manipulation, subjugation, and destruction, but also of escape and hope.

Several articles in the volume demonstrate how linguistic conversion was closely related to issues of religious conversion and identity. The adaptability of the texts and their translators makes evident the fluidity of both individual and communal religiosities at the time of their production. Some of the translations studied in these articles were written and probably used for polemical purposes. Others were humanistic projects or were used for liturgical purposes. Yet, as unifying or warning messages, missionary or teaching tools, they all became — willingly or unwillingly—part and parcel of cultural and often political interaction.

The established sacred quality of the source texts certainly gave prestige to the translations examined here, as well as to their composers and patrons. It also charged them with an authority outside the domains of spiritual or moral guidance with which these source texts are generally associated. When texts that were considered to be divinely inspired were translated, they could easily become instruments of political power. Indeed, for the premodern period, was there anything more powerful than having God's commanding voice behind one's cause?

It comes as no surprise that the political and religious authorities of the time wanted to be the sole manipulators of this power. Uncontrolled translation projects could easily turn into dangerous weapons. There are at least two reasons for this. Firstly, translation always involves some degree of interpretation. When the words being interpreted are considered divinely inspired, even the slightest shift in meaning becomes significant. In the case of the Abrahamic religions, which share much of their prophetic history and moral teachings, these differences were essential to create or cover the semantic distance

Research Council-Advanced Grant directed by Mercedes García-Arenal (ILC-CSIC) for the years 2013-2018. http://proyectos.cchs.csic.es/corpi/en.

2 The original name of the project is "Orientalismo y verdad. La influencia de la erudición oriental en el desarrollo del pensamiento crítico en la España moderna” (FFI2017-86538-P). The editors thank Fernando Rodríguez Mediano (ILC-CSIC) and Mercedes García-Arenal (ILC-CSIC), the directors of the project, for their kind insight and guidance during the preparation of this volume. I thank Katarzyna K. Starczewska for her comments and suggestions in preparing this introduction. 
between them. Control over this distance brought power to the authority in charge of the translation. Secondly, it was often the case that sacred texts were written in languages foreign to their believers. Their translation into vernacular made them accessible to a larger readership expanding their field of influence. Here, let us note that readers were also members of religious communities and subjects of states, and their obedience was essential for the religious and political authorities.

It is then this inherent capacity of translated sacred texts that have made them objects of manipulation, control, and even aggression. In the particular historical context of premodern Iberia, where, at diverse moments, all three of the Abrahamic religions strove for survival and where Islam and Christianity also strove for dominion, the authority of these translations transformed them into active participants in political, social, and cultural programs of division as well as cohesion.

In introducing the following five articles on late medieval and early modern translations of Jewish, Christian, and Muslim sacred texts, I will start with a brief note on the organization of the volume. A glance at the translations studied in terms of the common meanings of the verb "translate" will follow. An evaluation of the relationship between the political and cultural context in which these translations were prepared and the meanings and functions they acquired through the translation process will be presented in the next section. A reminder of the histories of the translations themselves will lead to the conclusion. As the reader will see, some of these histories are survival stories while others are chronicles of destruction. All, with no exception, offer us valuable clues and information for historical and linguistic research.

The volume begins with Biblical translations and ends with translations of the Qurann. The Torah and the Jewish rabbinical and literary tradition have varying degrees of presence in all but the first article. In the case of Gemma Avenoza's article the entire translation of Pope Gregory's Homiliarum in Ezechielem Prophetam Libri Duo with its prologue has survived to our day; we know both the translator (Gonzalo de Ocaña) and the patron (Queen Maria of Castile); and a completion date (1442) can be reasonably established. These known elements have opened the way for the author to iron out the translator's biography with new archival material and discuss his political stance as it is revealed in the prologue of his translation. What follows after the first article is a collection of translation stories with more complications, where often the author and his (her?) audience are not ostensibly known. 
In "Bible Translation by Jews and Christians in Medieval Catalan-speaking Territories," Pere Casanellas demonstrates how the study of Bible translations can contribute to a more profound knowledge of medieval Catalan while providing valuable insights into the historical background, religious-cultural context, and the linguistic details of the translations themselves. In "Canonical and Non-Canonical Sources for Biblical History in Two Arabic Universal Histories written by Christian in al-Andalus," Mayte Penelas offers us a privileged view into the intellectual history of the Mozarabs-i.e. Arabic-speaking Christians living in the Iberian Peninsula under Muslim rule. Her close reading of two Mozarabic universal histories reveals the rich array of sources that were used for these texts. Among these sources are biblical fragments, the chronicles of Jerome and Isidore of Seville, the History of Orosius, extracts from the Talmud, and possibly Eastern Christian sources circulating in alAndalus. In "Translation and Polemics in the Anti-Jewish Literature of the Muslims of Christian Iberia: The 'Conversion of Ka'b al-Ahbār' or the 'Lines of the Torah," Mònica Colominas examines how a well-known conversion narrative was translated, interpreted, and manipulated by the members of various Muslim communities in Christian Iberia to strengthen their faith and communal identity.

We followed a similar order of increasing complexity with respect to the correspondence between the religious allegiance of the ruling authority at the time of the translation versus that of the audience of the translation studied. The reader will observe that the discrepancy between the two is reflected in the degree to which the meanings and functions of the source texts were transformed.

We read in the first article that Gonzalo de Ocaña prepared a Biblical translation under a Christian authority. In fact, one of the main representatives of this authority, the Queen, was also his main audience. Casanellas's Christian, converso, and Jewish translators also produced under Christian authorities, but their audience was as variegated in their religious identity as themselves. The Mozarabic protagonists of Penelas's study worked under Muslim rule for Christian audiences whereas the Morisco (i.e. Iberian Muslims converted to Christianity by force) translators studied by Colominas wrote anti-Jewish polemics for their community, which most probably included Jewish converts, oppressed by Christian authorities.

The last article in this volume, Benoît Grévin's study, "Late Medieval Translations of the Qurān (1450-1525): Discontinuity or Cumulativeness?," is slightly different from those preceding it as it addresses a conceptual question: why were the earlier two Quran translations from the twelfth and the thirteenth centuries much more widely used in Western scholarship before the 
nineteenth century, instead of the three known translations from the late fifteenth and early sixteenth centuries, when the latter were intellectually more sophisticated than the former?

This is a question that we consider relevant not only to the scrutiny of premodern translations of sacred texts but also, and more self-consciously, to our own intellectual pursuits as scholars. Knowledge that we inherit and to which our studies contribute has its own evolutionary history marked by choices that were made and accidents that happened. Received scholarship has already attained a form that conditions our research. Intellectual trends, political pressures, natural calamities and wars, as well as chance, determine the quantity and nature of the documents left to us. They also determine a large part of the array of perspectives we deem available. As scholars, we strive to add our grain of salt to cumulative scholarship, while accepting that the possibility of discontinuity exists and is inevitable.

Perhaps as a reaction to this difficult realization, Grévin does not simply conclude his article, as one would expect, after tackling the conceptual question he introduced in the title. Instead, he starts a new dialogue. He offers his own variation to the methodology of comparative textual analysis and proposes a special relation between two of the Qurān translations he discussed earlier in his article, that of Marcos de Toledo and Moncada's partial translation in the Vatican library (MS. Vat. Ebr. 457). In this way, by laying out a new methodology and launching a new hypothesis at the end of his article, he makes a proposition for cumulative knowledge and defies discontinuity.

To better understand the different aspects of the translations examined in the collection, let us begin with the meaning of the word "translate" itself.

The first definitions given for the transitive verb "translate" in Meriam Webster are the following:

1. a : to turn into one's own or another language

b : to transfer or turn from one set of symbols into another: transcribe

c (1): to express in different terms and especially different words: to paraphrase

(2): to express in more comprehensible terms: explain, interpret

2. a : to bear, remove, or change from one place, state, form, or appearance to another: transfer, transform ${ }^{3}$

3 https://www.merriam-webster.com/dictionary/translate. Last accessed on the 5 August 2020. 
The articles in this volume cover all of the meanings listed above. The texts studied were translated into the translators' own language or to another (1a). In effect, both the source and the target language of the translations discussed display an impressive variety. Gemma Avenoza, Pere Casanellas, and Mayte Penelas mention translations of the Bible and Christian canonical literature from Latin, Hebrew, Greek, Aramaic or Catalan to Castilian, Catalan, Arabic, or Hebrew. In the case of Qurannic translations, the expected shift from one linguistic structure to another is complicated further by the change in transcription, the "transfer or turn from one set of symbols into another," as stated in the definition above (1b). The Qur'ānic translation of Juan de Segovia and his collaborator Iça Gidelli (1456), or the one commissioned by Egidio da Viterbo (first version 1518, corrected version 1525), both of which Benoît Grévin refers to in his study, for example, are prepared in several languages and scripts organized in different columns. Likewise, many of the references and quotations from the Qurān, the Torah, and the Gospels that Mònica Colominas discusses in her article are written in Aljamiado-i.e. Romance language written with the Arabic script.

Often translations are influenced by other, earlier translations. In some of the articles, the reader will see that these earlier translations accompanied the translator as comparative texts while he toiled on his own work. At other times, the records of these other translations in his memory were reproduced in paraphrased passages and in anthologies, or florilegia. Both Avenoza and Casanellas mention the role of memory as a source for medieval and early modern translations. In Avenoza's article ("The Old Testament in Translated Patristic Works: Ezekiel 1-4:3 and 40:1-47 in Fr. Gonzalo de Ocaña's (1442) Castilian Translation of Homiliarum in Ezechielem Prophetam Libri Duo by Pope Gregory I"), the dedicatory prologue that Gonzalo de Ocaña presented with his translation to the Queen of Castile, Maria, offers us a perfect example of a short florilegium of biblical fragments reproduced, often in paraphrases, from the friar's memory (1c-1). In this particular case, it was concocted carefully to admonish the queen for supporting her brothers against her husband in the political strife at the time.

As irreverent as it may sound to our ears when talking about translation, paraphrasing was a method used when the educative and polemical reasons for undertaking a translation were prioritized over purely academic ones, as in the case of some premodern Qurānic translations. Yet, this does not mean that the translator did not demonstrate the necessary rigor in performing his task or pay the due respect to the source text. Robert of Ketton's translation (1142-1143) is perhaps the most renowned example of this method where further study has confirmed his solid knowledge of Qur'ānic exegesis and his firm intention to render it albeit without introducing any categorical separation 
between translation and exegesis. ${ }^{4}$ The chart in Grévin's article represents the variations, such as those between the translations of Robert of Ketton, Marcos de Toledo (c. 1210), and Moncada (c. 1489), of the same Qurānic passage (Maryam 1-40) and in this way, exemplifies the results of the translators' efforts to express the same passages in more accurate or comprehensible ways, once again, carrying out the act of translating as defined by Meriam Webster $(1 \mathrm{c}-2)$. Here, we should also note that in these efforts literality, elegance, and lucidity were negotiated often more freely than they would be in our times.

Of course, the change of form indicated in the lexicon above (2a) also applies to all of the translations examined in this volume. As mentioned previously, occasionally this formal transformation affects both the language and the script of the text. Moreover, the transformation that concerns the translations of the sacred texts at issue here often involves transformations of the spirit of the original text, as well.

In Mayte Penelas's article, for example, we observe how biblical and nonbiblical (including non-canonical) sources were used in the composition of two Mozarabic universal histories, the so-called Kitāb Hurüshiyūsh and the Mozarabic Universal History. We do not know if the relevant sacred texts were translated by the authors of these codices or if they used texts already translated into Arabic. In either case, the writers paraphrased their sacred sources with varying degrees of liberty and used them as building blocks for their world histories where biblical history and the history of early Christianity were amplified and given a prominent place. In other words, they used translations of sacred and profane texts together, converting them to integral parts of a different type of narrative, one that is historical and, as is often the case with histories, political.

Not in all of the translations treated in this volume, sacred texts are used as pieces to form another-and often non-sacred-type of text. Still, even when we are dealing with sections of the Bible or the Qurān that are translated in their entirety, as in the cases studied by Avenoza, Casanellas, and Grévin, the transfer of the source text into the grammar and lexicon of the target language implies a shift that goes beyond the already significant discrepancies between the linguistic and cultural mentalities operating in these two languages. In all cases studied in this volume, the political and cultural contexts in which the translation projects were undertaken play a decisive role in defining their form and significance. Exploring these contexts helps us understand the more profound transformation the translations went through.

4 Thomas E. Burman, Reading the Qur'ān in Latin Christendom, 1140-1560 (Philadelphia: University of Pennsylvania Press, 2007). 


\section{Political and Cultural Context of the Premodern Translations of Sacred Texts}

Premodern translations were often commissioned by persons of authority for individual use or in the name of institutions. In the former case, the texts produced provide us some access to the mentality and tastes of the commissioner both as an individual agent in his/her own right and as a member of the larger community in which he/she lived.

Avenoza, for example, suggests that Queen Maria's interest in the passages of the Book of Ezekiel that she asked Gonzalo de Ocaña (d. between May 1446 and end of January 1447) to translate might have stemmed from her curiosity in apocalyptic literature. This type of literature had been used in favor of her two brothers, the Infantes of Aragon, in their struggle against her husband, John II of Castile (r. 1406-1454); and the queen gave clear support to her brothers' faction. This political context not only offers us a possible reason for the queen's choice in the text to be translated, but it also sheds light on the reasons for Gonzalo de Ocaña's interpolations in the previously mentioned anthological preface to his translation, where he manipulates Biblical material in accordance with his own political stand on the side of the king. Resembling a preacher rather than a translator, in this section, he sternly advises the queen to act on the principles of peace and justice instead of being governed by what he calls "the love of relatives."

Even though in the main body of his translation, the friar remains literally loyal to Pope Gregory's text, his prologue sets a certain tone to the project as a whole. In the absence of relevant documents, we can only imagine the queen's reaction as she read the translator's rebuke. Be that as it may, it is clear that what the queen expected from the translation as its commissioner differed from what the translator wanted to offer. These two visions concerning the text, its meanings, and possible functions also diverged from what Pope Gregory might have expected to achieve with his translation, and certainly from the possible expectations of the original writers of the Book of Ezekiel. As the historical circumstances evolved, each translation attained different meanings and served different functions. Disregarding these circumstances and their dynamics would impede an accurate and comprehensive evaluation of the text.

In the case of translations of sacred texts for polemical purposes, the distance between the texts' initial and later significance is even more apparent. Latin translations of the Qur'ān, for example, were frequently used to refute Islam. However, they were not the only translations done for polemical 
purposes in early modern Iberia. In Mònica Colominas's article, we see that just like the Christians used Muslim scriptures for polemical struggles against Muslims, so the Muslims from the Christian territories fed their refutations of Judaism with translated Islamic and non-Islamic sources.

Colominas examines the narrative of Ka $\mathrm{b}$ al-Aḥbār's conversion from Judaism to Islam as it was presented in a number of written sources. Using Walid Saleh's concept of "constructing ambivalence,"5 she argues that the translations of the well-known conversion story aimed at strengthening the communal bonds of the Moriscos and their faith in Islam. One of the manuscripts that includes the conversion narrative is a late fifteenth-century copy written in Romance using Arabic characters (Aljamiado). Colominas argues that the content and language of this manuscript suggests that its targeted audience was possibly a community of converts from Judaism to Islam with an intimate knowledge of Judaism and Jewish sources.

As in every conversion narrative, in Ka $\mathrm{b}$ al-Aḥbār's story too, the religion converted to, that is Islam, is presented as triumphant. The fact that Ka'b's conversion was the result of his discovering of a truth hidden by his most trusted masters in Jewish theology ties Islamic faith to divine truth as much as it associates Judaism with hypocrisy and lies. At the same time, by presenting the knowledge of the arrival of Islam as an ancient truth within the original Jewish creed, it places Islam at a chronologically earlier and more prestigious position in the Abrahamic chain of religions. This strategic manipulation of sacred history must have helped restore the morale and the damaged self-conception of a community humiliated by defeat.

Previously, we have mentioned a parallel case in reference to Penelas's article. There, it was the Christians of al-Andalus who used biblical and nonbiblical sources to place early Christian history in an especially prominent place. In Colominas's article, the historical circumstances are reversed, and it is the Moriscos who are using, translating, and interpreting passages from the Qur'ān, the Talmud, and the Gospels in a similar effort to manipulate the past to solidify their communal identity. In both cases, the discrepancy between the religion of the governing political authority and that of the writers and their audience is acutely relevant in evaluating the translations.

Nevertheless, in the late fifteenth century, when the Aljamiado manuscript in Colominas's article was written, most of the Jewish converts were Christian.

5 Walid Saleh, "The Hebrew Bible in Islam," in The Cambridge Companion to the Hebrew Bible/ Old Testament, ed. Stephen B. Chapman and Marvin A. Sweeney (Cambridge: Cambridge University Press, 2016), 407-425 at 411-412. 
One such Jewish convert from Sicily, Flavius Mithridates, better known as Moncada, was active in the court of Federico da Montefeltro, the Duke of Urbino (d. 1482). In the very early 1480s, he was involved in several translation projects. One of these projects was a luxury codex that contains his translation of the twenty-first and twenty-second suwar of the Qurān. Here, Moncada also gives the glad tidings of a more ambitious future project to write a quadrilingual Arabic-Hebrew-Aramaic-Latin Qurān. It seems that he had already discussed this with his patron. In his article, Grévin observes that Moncada's copious interlinear translation notes and marginal exegesis in another codex, an enigmatic fifteenth century Qurān in Hebrew characters, indicate the same interest in producing a polyglot translation of the Qur'ān. Would it be possible to understand and study these translation activities and the texts produced without taking into account the strong influence of humanism in the intellectual history of northern Italy in this period? Indeed the Duke of Urbino was known as a leading bibliophile and a patron of arts and architecture. His private scriptorium enriched by ambitious editorial and translation projects rivaled the Vatican library of the time in comprehensiveness. ${ }^{6}$ We also know that after the Duke's death, in the later 1480 s, Moncada worked as a language teacher for the famous Renaissance nobleman, humanist, and philosopher Giovanni Pico della Mirandola.

The five biblical translations in Catalan, known as the Fourteenth-Century Bible, offer us another example of the importance of the cultural context when studying a translation project. This Catalan Bible, discussed in Casanellas's article, was produced during the reign of Peter III "the Ceremonious" (r. 13361387) when translations in general and those of Latin classics in particular were promoted.

Just as the knowledge of historical circumstances facilitates our understanding of translated texts, the linguistic analysis of texts also informs historical scholarship. The previously mentioned case of Gonzalo de Ocaña's translation for Queen Maria of Castile, for example, is one where linguistic and historical studies equally benefit from this interdisciplinary exchange of knowledge. Indeed, textual analysis offers much valuable information about political, social, and intellectual history, especially on the circulation of books.

6 The catalogue book of a recent exhibition on the Duke displays his humanistic interest in the Eastern Mediterranean with many examples from his patronage of the arts, literature, and architecture. Il Montefeltro e l'Oriente islamico: Urbino 1430-1550: il Palazzo Ducale tra Occidente e Oriente, ed. Alessandro Bruschettini (Genova: Sagep editori, 2018). 
Mayte Penelas writes that various aspects of the two universal histories, Kitāb Hurūshiyūsh and the Mozarabic Universal History, provide evidence for some of the sources circulating among the Christians in al-Andalus, possibly including eastern Christian books on early Christian history. Moreover, these universal histories bear witness to the process of Arabization that the community underwent.

According to Mònica Colominas, it is highly likely that translation activities involving Ka'b al-Ahbār's conversion narrative offered a main avenue for the circulation and shaping of knowledge on Jewish texts and practices among Castilian and Aragonese Mudejars (i.e. Muslims of Iberia under Christian rule) and Moriscos until their expulsion in the seventeenth century. The possible presence of recent converts from Judaism among the readers of the Aljamiado manuscript she discusses in her article highlights the complexity of the history of Iberian Jews and Muslims towards the end of the Reconquista, contributing to our understanding of reactions to religious and political oppression.

Another example is the Fourteenth-Century Bible. The textual analysis of the five books constituting this work yielded variants that diverged from the standard Vulgate, the translation's main source. Pere Casanellas writes that some of these differences stemmed from the variants circulating in Catalan speaking territories of the time. The influences of Occitan and French, particularly in the New Testament and the books from the second half of the Old Testament, add further nuances to the rich linguistic and cultural context that produced these five manuscripts. Moreover, we read in the same article that certain details in the texts of some of the books suggest that their translators might have been Jewish converts, who introduced vocabulary and notions they had memorized from both the Hebrew Bible and the rabbinical tradition. This is especially the case in the books of Exodus, Leviticus, and Psalms, particularly in the Peiresc and Colbert manuscripts.

Nevertheless, it is important to avoid establishing automatic relationships between the translations we examine and their historical circumstances. Linguistic details might provide significant hints concerning the identities of the translators and their audience. However, the religious or communal identities of translators do not determine the nature of their writing. Going back to our example, we cannot assume that Jewish or converso translators necessarily brought influences from Hebrew sources or the Jewish tradition to every, in fact to any, translation they undertook. For instance, Casanellas writes that one such converso translator named Daniel Vives worked under the supervision of the Dominican inquisitor Jaume Borrell to ensure that the text of the Fifteenth-Century Bible (known also as the Valencian Bible, or the Bible 
of Bonifaci Ferrer) followed that of the Vulgate as closely as possible. Indeed, his adherence to Latin was so adamant that aside from the highly Latinized vocabulary, the sentence structure of the Catalan text became what Casanellas calls "one long Latin calque."

\section{Translated Sacred Texts and Their Histories of Destruction} and Survival

Not only the linguistic details but also the history of the manuscripts themselves contribute to scholarship. The abundance of translations can be tied to patronage activities, like those of Peter III "the Ceremonious," who promoted translations of the classics into Catalan, or of the Duke of Urbino, who was intent on building the leading library of his time and hired Moncada among others. Avenoza writes that the medieval French court's interest in translations of the Bible is one of the reasons for the stark contrast of around two hundred Bible translations into French to twenty-seven codices or manuscript fragments of biblical translations into Castilian. In her article, she also gives us other important reasons for the poor numbers in Spain, such as the dispersal of aristocratic and convent libraries, and the Inquisitorial orders to destroy biblical texts in vernacular languages. Indeed, destruction has been a part of the history of translated sacred texts at least as much as promotion and patronage.

A telling example is the Fifteenth-Century Bible mentioned above. Despite the palpable Latinizing tendencies of the text revised by the converso Daniel Vives under the surveillance of a Dominican inquisitor, action was taken against it in 1483 , right before the Bible burnings. Vives was imprisoned. Of the 600 copies of the translation printed in 1478 only one known copy remained in the Royal Library of Stockholm.

The biography of this translation does not end here. In 1697, an accidental fire destroyed this last copy, adding insult to injury. Still, to scholars' relief, there are two significant and reliable remnants of this translation project. The last folio containing the final part of the Book of Apocalypse (from 20.8 [= Vg 20.9] to 22.21) and the colophon is preserved in the library of the New York Hispanic Society. In addition, a copy of the Psalter reprinted in Barcelona around 1480 has survived despite several Bible burnings. It is preserved in the Bibliothèque Mazarine in Paris.

Not every translation had the "fortune" of the Fifteenth-Century Bible and could rise from the ashes of destruction like the Phoenix, albeit losing most of its feathers. Many copies are lost to history, some with no mark of their existence. Some of these copies might have had significant circulation and a large 
audience. Some could have been much better known and have had more significant impact on their users than the copies that remained for us to study and on which we base our deductions. Nevertheless, the panorama is not totally dark and gloomy. Each twist and turn of the bumpy history of translated sacred texts holds potential information. Both the bans and the burnings as well as scarcity and abundance of copies have added to our knowledge of the political, social, and cultural history of the period.

As Casanellas reports, the ban on translations of the Bible issued by the Catalan Ecclesiastical Court of 1235, for example, originally aimed at protecting the faithful from the heretical interpretations of groups, such as the Cathars and Albigensians, that could have easily left its mark on the translations. For the Ecclesiastical Court, the danger was especially acute in the case of the New Testament. While the ban remained in vigor until the eighteenth century, it was more rigorously practiced in times of crisis. In normal times, translations of sacred texts used for prayer were often exempted from the ban, hence the abundance of Catalan translations of the Psalms.

Even the archives of destruction hold information. We learn from the documentation on the Bible burning in Valencia in 1447 , for example, that among the burnt codices, there were eight or nine copies of the Old Testament in Catalan owned by conversos and Jews.

The acts of prohibition and destruction that soured the histories of many premodern translation projects reveal the repetitive efforts of the religious institutions to control the meanings and functions of what they considered sacred. In these efforts, they often collaborated with the political authorities, in the case of the present collection, with the Crowns of Castile and Aragon. As the five articles in this collection also display, the motivations behind translating were varied and they did not necessarily serve the interests of the predominant religious or political authorities. Nor did they always intend to. Some translations served didactic purposes and facilitated a better and "more correct" comprehension of the tenets of the faith, whether it be the faith approved by the dominant religious authority or other. They also helped protect religious communities from dissolution when in dire straits, for teaching sacred texts in the language common to the community was useful in adequately equipping the believers against temptations or pressures to convert to another religion. Translating sacred texts of a rival religion, on the other hand, was crucial for an informed refutation in polemical situations.

The articles in the collection can also be read from an alternative perspective, as a prelude to what is to happen in the first decades of the sixteenth century. A new page was turned on the history of translating sacred texts with Erasmus's edition of 1516 , which contained the original Greek text as well as a 
new Latin translation. In 1521, during his forced sojourn in Wartburg, Martin Luther used the second edition of this translation to prepare his own version of the New Testament in German. Luther continued his biblical translations with the Pentateuch (1523). In 1524, he translated the Psalms based on the Hebrew Old Testament and his Greek translation of it, the Septuagint. By 1534, he had, with a group of translators, translated all the books in the Old Testament including the Deuterocanonical books, which were not accepted as part of the Hebraic Canon for being written in Greek or Aramaic instead of Hebrew.

Luther's translation project expands Erasmus's humanistic effort in using various source texts written in different languages to reach a more accurate translation. This interest in languages brings to mind Moncada's similar translation projects discussed in Grévin's article. Moreover, Luther's project assumes a certain distance between the linguistic form of the text and its meaning. Rather than perceiving the diversity of languages as a risk of contaminating the pure meaning of a chosen and unique source text, this approach strives to use it to reach truths believed to be behind and beyond words in any language. Such a perspective that champions the independence of truth from form facilitates the path to translations of sacred texts to any language. This also means that, the vernacular, the language of "the mother in the home, the children on the street, the common man in the marketplace," as Luther would have it, is raised to the level of a host language that is to receive and express divinely inspired words. ${ }^{7}$

Backed by printing technology, the Bible in the vernacular became in short time impossible to contain. By 1546 half a million copies of complete Bibles, printed in over ninety cities, were in circulation, and available for about two florins. Such a situation would have been a nightmare for the Inquisitorial persecutors of Daniel Vives and his translation in 1483.

The Islamic context with respect to translation was and has been different. "Inspired language can never be completely satisfactorily translated into another language," wrote Fazlur Rahman in a 1988 article on translating the Qurān. ${ }^{8}$ He was of the opinion that "great poetry is generally not successfully translatable." ${ }^{\prime}$ In the case of the Islamic holy book, aside from the linguistic challenges that hindered the task, there were other fundamental problems. It

7 Martin Luther, "An Open Letter on Translating," trans. Gary Mann, rev. Michael D. Marlowe from „Ein sendbrief D. M. Luthers. Von Dolmetzschen und Fürbit der heiligenn" in Dr. Martin Luthers Werke, (Weimar: Hermann Boehlaus Nachfolger, 1909), Band 3o, Teil II, 632-646. The translation also includes the German text from the Weimar edition of Luther's works. Last accessed on the 13th of September, 2020 at http://www.bible-researcher.com/luthero1.html.

8 Fazlur Rahman, "Translating the Qur’an," Religion \& Literature 20:1 (Spring 1988): 23-30 at 24.

9 Rahman, "Translating the Qur’an," 24. 
was not a single book written by an author, but rather an assembly of divine messages communicated to Muhammad. A human translator would not be capable of substituting God's words "completely satisfactorily." Furthermore, no other linguistic medium for a target text would be adequate. In fact, the Qur'ān "declares itself ... to be an absolutely unique and inimitable Arabic Qur'an, the like of which cannot be reproduced in Arabic, nor, of course, in any other language." 10

Of course, Rahman was not trying to say that translating the Qur'ān was sacrilegious. In fact, in the same article, he translates various lines of the Book and compares the rendering of several Qur'ānic passages in other translations, sharing his evaluation with the reader. What he was referring to when he was talking about the translation of an inspired text in general was the substitution of that text in a different form (language) but with a complete and identical inspiration. Naturally, it would be nearly impossible for the inspiration of the poet and the translator to coincide. When the composer of the text, or more accurately said, the origin of an assembly of messages, was believed to be God, this became utterly impossible. Besides, in the case of the Islamic sacred text, the form, i.e. its particular Arabic, and its divine spirit, could not be separated without contradicting the self-reflection included in the Qurān to which Rahman was referring. A perfect translation of the Islamic sacred text was hence unrealizable, but the pursuit of translating the Qurān was still worthy. In fact, translation, like exegesis, was necessary for the human understanding of God's message.

Rahman's view on translation of the divinely inspired text of the Qur'àn is not a modern notion. Translations to the vernacular in Islam did not suffer a history similar to their counterparts in Christianity. Printing arrived late for copies of the Qurann in Arabic, and the empowering yet problematic sacredness of the Holy Book remained more closely attached to the Arabic Qur'ān and not to its translations. What this attachment of the form and content in reference to the Islamic sacred text meant and whether it was ever contested are questions that involve a larger discussion.

For our purposes here, and as a last word, I believe it important to underline the benefits of interdisciplinary exchange between literary and linguistic studies, on the one hand, and political, social, and cultural history on the other, when studying premodern translations of sacred texts. Texts, as cultural products, are among the most personal documents to which a historian has access. They expose the political and cultural interests, tastes, motives, preferences, and fears of individuals and the institutions these individuals constitute. 
Their linguistic scrutiny and literary contextualization make any historical study richer and more accurate. As the articles in this collection display, better understanding the histories behind them and the difficulties and controversies that these translations encountered and provoked facilitate valuable insights into the social and political concerns of different communities and the formation of their identity. In this way, a historical examination offers us information on the authors, commissioners, and the readers of the texts we study, advancing our comprehension of the linguistic choices made in the texts.

We believe that all of the five articles in this volume will become meaningful and useful contributions to present knowledge on premodern translations and cultural history and hope that the reader finds the collection as informative and thought-provoking as we have. 